\title{
Ecological differentiation in Rumex crispus L. natural populations in metal mining areas
}

\author{
Yajing Zhang \\ Yunnan University \\ Huaju Yang \\ Yunnan University \\ Yue Wang \\ Yunnan University \\ Chundong Tang \\ Yunnan University \\ Chang'e Liu \\ Yunnan University \\ Yonggui Zhao \\ Yunnan University \\ Shiyu Li \\ Yunnan University \\ Changqun Duan ( $\nabla$ chqduan@ynu.edu.cn )
}

\section{Research article}

Keywords: Metal pollution, Phenotypic traits, Ecological differentiation, Phenotypic variation

Posted Date: February 28th, 2020

DOI: https://doi.org/10.21203/rs.3.rs-15476/v1

License: (9) (1) This work is licensed under a Creative Commons Attribution 4.0 International License. Read Full License 


\section{Abstract}

Background: Variations in phenotypic traits of various plants living in either normal or stressed environments have been well studied, but ecological responses of plants to long-term persistent toxic metal pollution have little been reported. In this study, in order to explore the effects of continuous metal pollution in soil on variation and differentiation in the plants, Rumex crispus $\mathrm{L}$. populations exposed to different levels of long-term persistent toxic metal pollution were studied, and corresponding $R$. crispus populations that had not been exposed to pollution were used as controls.

Results: Six phenotypic traits of $R$. crispus-root diameter, leaf area, leaf length, leaf width, leaf perimeter, and leaf length-to-width ratio-differed significantly among and within populations. Traits ranked in descending order of coefficient of variation were leaf area, leaf perimeter, root diameter, leaf length, leaf width, leaf length-to-width ratio. The average coefficient of variation was $46 \%$. Phenotypic variation in R. crispus was much greater among populations $(92.69 \%)$ than within populations $(6.55 \%)$. The mean phenotypic differentiation coefficient (Vst) of $93.37 \%$ indicates that the interpopulation variability was the main source of phenotypic variation in $R$. crispus. Finally, root diameter was significantly positively correlated with metal factors, but leaf area, leaf length, and leaf aspect ratio were significantly negatively correlated with $\mathrm{Pb}, \mathrm{Zn}, \mathrm{Mn}$, and Fe contents. Overall, underground growth is superior to aboveground growth in populations that have experienced long-term exposure to toxic metal pollution, and there were phenotypic differences between uncontaminated and contaminated populations.

Conclusions: These results indicate that $R$. crispus adapts to the heterogeneous environment caused by toxic metal pollution through rich phenotypic variation, and ecological differentiation has occurred among different populations.

\section{Background}

Many human activities, such as industry, metallurgy, mining, the use of fertilizer containing heavy metal, and transportation, have resulted in the transfer, redistribution, and bioaccumulation of heavy metals in the natural environment $[1,2]$. Pollution of the soil with heavy metals poses a serious threat to all living systems, including humans, and has become a major global environmental problem [3]. The impact of long-term persistent heavy metal pollution on organisms, in particular on genetic diversity, is currently an important issue in both pollution ecology and environmental biology.

Genetic diversity is an important part of biodiversity. Research methods for determining genetic diversity include morphology, cytology, biochemistry, and the use of molecular markers. Phenotypic shape is an indirect estimate of genetic diversity. Variation in phenotypic traits is of great significance for both adaptability and evolution, and studying phenotypes can help researchers more intuitively predict both population genetic structure and the number of evolutionary adaptations [4]. Understanding the effects of environmental factors on plants through the study of plant morphology can also reveal the way in which plants adapt to heterogeneous environments and the relationships between plants and natural factors. Wang [5] found that long-term persistent toxic metal pollution changes plants' morphological structure and promotes ecological differentiation. In recent years, research on phenotypic variation in natural populations has mostly focused on species affected by geography, climate, and physical and chemical properties of the soil [6-9]. Other research has included basic studies on phenotypic diversity in plant resources for conservation $[2,10]$ and toxicity. There are few reports on ecological differentiation caused by metal pollution.

The Yunnan Province of China is known as the "The Kingdom of Non-ferrous Metals," and toxic metal contamination in the soil is increasing because of mining activity [11]. The city of Gejiu has a wide variety of mineral resources, and heavy metal pollution in mining process is more complicated in this area than in other parts of the country. The complexity of the city's toxic metal pollution makes this region an ideal area for studying the relationship between plants and soil contaminated with toxic metals. Rumex crispus is a perennial wild plant that grows well in mining areas. Xue and Liu [12] found that R. crispus is resistant to a variety of heavy metals, including certain accumulations of $\mathrm{Pb}, \mathrm{Zn}$, and $\mathrm{Cu}$, but a poor accumulation of $\mathrm{Cd}$, which can be used for soil remediation and restoration in mining areas. However, the adaptation of R. crispus to persistent toxic metal pollution and the ecological implications of phenotypic variation for characterizing and indicating the long-term persistent toxic metal pollution environment has not been studied. 
In this study, in order to explore the ecological differentiation and the ecological response of plants to long-term persistent toxic metal pollution, we investigated differentiation in Rumex crispus populations exposed to long-term toxic metal pollution and those that had not been exposed to pollution. We measured phenotypic traits of each R. crispus population and levels of metal in the soil and used nested analyses of variance, coefficients of variation, correlation analyses, and cluster analyses to analyze phenotypic variation within and among populations. We also explored correlations between plant phenotypic variation and metal factors to better understand plant strategies for adapting to polluted environments.

\section{Materials And Methods}

\section{Sampling}

Our study area was different metal mining areas in the city of Gejiu in southwestern China. Gejiu is located in a low-latitude subtropical high-prototype humid monsoon climate zone with an average annual rainfall of $2026.5 \mathrm{~mm}$ and an average annual temperature of $16.4^{\circ} \mathrm{C}$. In April 2019, seven populations around these mines that had experienced continuous toxic metal pollution were investigated, and two populations in the neighboring city of Mengzi that had not been exposed to pollution were selected as controls (Table 1). We first measured latitude and longitude with GPS and measured altitude. Depending on the size of the original population, 7 to 13 individuals from each population were randomly selected for inclusion in the study. Three basal leaves were selected from each R. crispus plant, and leaf traits were measured with a portable handheld laser leaf area meter (CL203, American CID Corporation). The root diameter where the root is connected to the stem of each plant was measured with Vernier calipers. We took mixed soil samples at a depth of $0-30 \mathrm{~cm}$ near the collected plants and brought these samples to the laboratory for analyses.

Table 1

Sampling locations and basic situation of sampling

\begin{tabular}{|lllllll|}
\hline Population & Region (City) & Locatity (Town) & Latitude & Longitude & Altitude $(\mathrm{m})$ & Number of plants \\
\hline CA & Gejiu & Laochang & $23^{\circ} 17^{\prime} 49^{\prime \prime}$ & $103^{\circ} 13^{\prime} 10^{\prime \prime}$ & 2330 & 12 \\
\hline CB & Gejiu & Laochang & $23^{\circ} 17^{\prime} 45^{\prime \prime}$ & $103^{\circ} 12^{\prime} 60^{\prime \prime}$ & 2360 & 12 \\
\hline CC & Gejiu & Laochang & $23^{\circ} 118^{\prime} 6^{\prime \prime}$ & $103^{\circ} 12^{\prime} 24^{\prime \prime}$ & 2370 & 10 \\
\hline WA & Gejiu & Wugushao & $23^{\circ} 19^{\prime} 14^{\prime \prime}$ & $103^{\circ} 10^{\prime} 13^{\prime \prime}$ & 1940 & 11 \\
\hline WB & Gejiu & Wugushao & $23^{\circ} 19^{\prime} 11^{\prime \prime}$ & $103^{\circ} 10^{\prime} 11^{\prime \prime}$ & 1870 & 12 \\
\hline WC & Gejiu & Wugushao & $23^{\circ} 19^{\prime} 5^{\prime \prime}$ & $103^{\circ} 9^{\prime} 56^{\prime \prime}$ & 1970 & 13 \\
\hline Y & Gejiu & Yangbadi & $23^{\circ} 17^{\prime} 25^{\prime \prime}$ & $103^{\circ} 16^{\prime} 18^{\prime \prime}$ & 1870 & 9 \\
\hline SH & Mengzi & Shuanghe & $23^{\circ} 56^{\prime} 58^{\prime \prime}$ & $103^{\circ} 16^{\prime} 17^{\prime \prime}$ & 1137 & 7 \\
\hline XG & Mengzi & Xinguang & $23^{\circ} 45^{\prime} 31^{\prime \prime}$ & $103^{\circ} 27^{\prime} 40^{\prime \prime}$ & 1291 & 7 \\
\hline Contaminated population: CA, CB, CC, WA, WB, WC, Y; uncontaminated populations: SH, XG. \\
\hline
\end{tabular}


Table 2

Basic physical and chemical properties and metal content in the soil at sampling points of Rumex crispus populations

\begin{tabular}{|c|c|c|c|c|c|c|c|c|c|c|c|c|}
\hline \multirow[t]{2}{*}{ Population } & \multirow{2}{*}{$\begin{array}{l}\text { SM } \\
(\%)\end{array}$} & \multirow[t]{2}{*}{$\mathrm{pH}$} & \multirow{2}{*}{$\begin{array}{l}\text { SOM } \\
(\mathrm{g} / \mathrm{kg})\end{array}$} & \multirow{2}{*}{$\begin{array}{l}\text { TP } \\
(\mathrm{g} / \mathrm{kg})\end{array}$} & \multirow[t]{2}{*}{$\mathrm{TN}(\mathrm{g} / \mathrm{kg})$} & \multicolumn{7}{|c|}{ Metal content (mg/kg) } \\
\hline & & & & & & Sn & $\mathrm{Pb}$ & $\mathrm{Zn}$ & $\mathrm{Cu}$ & Mn & $\mathrm{Fe}$ & As \\
\hline CA & 12 & $\begin{array}{l}7.66 \\
\pm \\
0.17\end{array}$ & $\begin{array}{l}5.52 \\
\pm 1.38\end{array}$ & $\begin{array}{l}0.35 \\
\pm 0.01\end{array}$ & $\begin{array}{l}0.42 \pm \\
0.12\end{array}$ & $\begin{array}{l}1374 \\
\pm 33\end{array}$ & $\begin{array}{l}7920 \\
\pm 88\end{array}$ & $\begin{array}{l}6543 \\
\pm 89\end{array}$ & $\begin{array}{l}1572 \\
\pm 43\end{array}$ & $\begin{array}{l}17237 \\
\pm 234\end{array}$ & $\begin{array}{l}130368 \\
\pm 1226\end{array}$ & $\begin{array}{l}2154 \\
\pm 52\end{array}$ \\
\hline $\mathrm{CB}$ & 7 & $\begin{array}{l}7.29 \\
\pm \\
0.28\end{array}$ & $\begin{array}{l}5.04 \\
\pm 0.69\end{array}$ & $\begin{array}{l}0.44 \\
\pm 0.04\end{array}$ & $\begin{array}{l}0.61 \pm \\
0.31\end{array}$ & $\begin{array}{l}3277 \\
\pm 47\end{array}$ & $\begin{array}{l}15392 \\
\pm 151\end{array}$ & $\begin{array}{l}9281 \\
\pm 114\end{array}$ & $\begin{array}{l}1730 \\
\pm 47\end{array}$ & $\begin{array}{l}35864 \\
\pm 389\end{array}$ & $\begin{array}{l}191722 \\
\pm 1684\end{array}$ & $\begin{array}{l}746 \\
\pm 64\end{array}$ \\
\hline $\mathrm{CC}$ & 34 & $\begin{array}{l}7.23 \\
\pm 0.2\end{array}$ & $\begin{array}{l}67.85 \\
\pm 9.16\end{array}$ & $\begin{array}{l}0.63 \\
\pm 0.03\end{array}$ & $\begin{array}{l}1.81 \pm \\
0.06\end{array}$ & $\begin{array}{l}2243 \\
\pm 36\end{array}$ & $\begin{array}{l}4220 \\
\pm 49\end{array}$ & $\begin{array}{l}4500 \\
\pm 62\end{array}$ & $\begin{array}{l}1355 \\
\pm 35\end{array}$ & $\begin{array}{l}7583 \\
\pm 136\end{array}$ & $\begin{array}{l}83403 \\
\pm 758\end{array}$ & $\begin{array}{l}1871 \\
\pm 37\end{array}$ \\
\hline WA & 2 & $\begin{array}{l}7.63 \\
\pm \\
0.05\end{array}$ & $\begin{array}{l}46.67 \\
\pm 0.73\end{array}$ & $\begin{array}{l}0.87 \\
\pm 0.07\end{array}$ & $\begin{array}{l}0.89 \pm \\
0.03\end{array}$ & $\begin{array}{l}9363 \\
\pm 99\end{array}$ & $\begin{array}{l}2367 \\
\pm 37\end{array}$ & $\begin{array}{l}2569 \\
\pm 53\end{array}$ & $\begin{array}{l}5733 \\
\pm 91\end{array}$ & $\begin{array}{l}2311 \\
\pm 84\end{array}$ & $\begin{array}{l}170711 \\
\pm 1593\end{array}$ & $\begin{array}{l}8572 \\
\pm 94\end{array}$ \\
\hline WB & 15 & $\begin{array}{l}7.69 \\
\pm \\
0.05\end{array}$ & $\begin{array}{l}69.11 \\
\pm 1.53\end{array}$ & $\begin{array}{l}0.44 \\
\pm 0.01\end{array}$ & $\begin{array}{l}2.74 \pm \\
0.09\end{array}$ & $\begin{array}{l}2411 \\
\pm 38\end{array}$ & $\begin{array}{l}1797 \\
\pm 28\end{array}$ & $\begin{array}{l}1811 \\
\pm 38\end{array}$ & $\begin{array}{l}2671 \\
\pm 52\end{array}$ & $\begin{array}{l}2372 \\
\pm 79\end{array}$ & $\begin{array}{l}95292 \\
\pm 873\end{array}$ & $\begin{array}{l}2560 \\
\pm 37\end{array}$ \\
\hline WC & 2 & $\begin{array}{l}7.4 \\
\pm \\
0.13\end{array}$ & $\begin{array}{l}65.55 \\
\pm 2.99\end{array}$ & $\begin{array}{l}0.57 \\
\pm 0\end{array}$ & $\begin{array}{l}2.57 \pm \\
0.05\end{array}$ & $\begin{array}{l}2880 \\
\pm 41\end{array}$ & $\begin{array}{l}3564 \\
\pm 44\end{array}$ & $\begin{array}{l}1609 \\
\pm 36\end{array}$ & $\begin{array}{l}1879 \\
\pm 43\end{array}$ & $\begin{array}{l}2940 \\
\pm 86\end{array}$ & $\begin{array}{l}111260 \\
\pm 996\end{array}$ & $\begin{array}{l}3151 \\
\pm 45\end{array}$ \\
\hline Y & 4 & $\begin{array}{l}7.7 \\
\pm \\
0.03\end{array}$ & $\begin{array}{l}52.39 \\
\pm \\
33.82\end{array}$ & $\begin{array}{l}0.56 \\
\pm 0.02\end{array}$ & $\begin{array}{l}2.95 \pm \\
0.21\end{array}$ & $\begin{array}{l}1784 \\
\pm 32\end{array}$ & $\begin{array}{l}4219 \\
\pm 48\end{array}$ & $\begin{array}{l}2494 \\
\pm 44\end{array}$ & $\begin{array}{l}1469 \\
\pm 38\end{array}$ & $\begin{array}{l}6495 \\
\pm 119\end{array}$ & $\begin{array}{l}124705 \\
\pm 1054\end{array}$ & $\begin{array}{l}1753 \\
\pm 36\end{array}$ \\
\hline $\mathrm{SH}$ & 10 & $\begin{array}{l}7.27 \\
\pm \\
0.06\end{array}$ & $\begin{array}{l}72.38 \\
\pm 2.38\end{array}$ & $\begin{array}{l}0.79 \\
\pm 0.01\end{array}$ & $\begin{array}{l}5.45 \pm \\
0.25\end{array}$ & $\begin{array}{l}124 \\
\pm 21\end{array}$ & $\begin{array}{l}736 \pm \\
14\end{array}$ & $\begin{array}{l}1333 \\
\pm 27\end{array}$ & $\begin{array}{l}178 \\
\pm 16\end{array}$ & $\begin{array}{l}875 \pm \\
55\end{array}$ & $\begin{array}{l}44291 \\
\pm 400\end{array}$ & $\begin{array}{l}242 \\
\pm 12\end{array}$ \\
\hline$X G$ & 19 & $\begin{array}{l}7.46 \\
\pm \\
0.11\end{array}$ & $\begin{array}{l}32.48 \\
\pm \\
29.19\end{array}$ & $\begin{array}{l}0.31 \\
\pm 0.02\end{array}$ & $\begin{array}{l}0.52 \pm \\
0.09\end{array}$ & $\begin{array}{l}0 \pm \\
736\end{array}$ & $\begin{array}{l}225 \pm \\
8\end{array}$ & $\begin{array}{l}382 \\
\pm 18\end{array}$ & $\begin{array}{l}155 \\
\pm 18\end{array}$ & $\begin{array}{l}1023 \\
\pm 57\end{array}$ & $\begin{array}{l}93104 \\
\pm 773\end{array}$ & $\begin{array}{l}108 \\
\pm 8\end{array}$ \\
\hline
\end{tabular}

\section{Determination Of Soil Environmental Factors}

The collected soil samples were first weighed to determine soil moisture, then air-dried in an air-drying room. When the samples were completely dry, they were ground up. Then they were mixed thoroughly on a colorless polyethylene film, passed through a $2 \mathrm{~mm}$ sieve and a $0.15 \mathrm{~mm}$ sieve, and put into Teflon bags until their indicators could be measured.

Determination of metal content of the soil: Air-dried soil samples passed through a $0.15 \mathrm{~mm}$ sieve were placed in a sample preparation mold, and metal contents were measured with X-ray fluorescence spectrometry (Vanta handheld portable X-ray fluorescence analyzer, Olympus, USA). Each test was set up so that three parallel samples were measured simultaneously. Measurements were repeated three times, and the detection time was set above $120 \mathrm{~s}$.

Determination of physical and chemical properties of the soil: Soil moisture was measured with the gravimetric method. Soil pH was measured with the glass electrode method (ST5000 laboratory pH meter, Ohaus Instrument Changzhou). Organic matter was measured by external heating method with potassium dichromate oxidation. The Kjeldahl nitrogen method (K1305A semiautomatic azotometer, Shanghai Shengsheng Automatic Analysis Instrument) was used to determine total nitrogen. Acid solution-molybdenum antimony colorimetry (UV1901PCS double-beam UV-spectrophotometer, Shanghai Youke Instrument) was used to determine total phosphorus. 


\section{Calculation of the coefficient of variation and phenotypic differentiation coefficient}

We calculated the coefficient of variation (CV) of phenotypic traits according to the following formula: $\mathrm{CV}=\mathrm{SD} / \mathrm{Mean}$. In this formula, SD is standard deviation.

The phenotypic differentiation coefficient was used to further measure the degree of phenotypic differentiation among populations according to the following formula: $\mathrm{V}_{\mathrm{st}}=\delta_{2 \mathrm{t} / \mathrm{s}} /\left(\delta_{2 \mathrm{t} / \mathrm{s}}+\delta_{2 \mathrm{~s}}\right)$. In this formula, $\mathrm{V}_{\mathrm{st}}$ is the phenotypic differentiation coefficient, $\delta_{2 t / s}$ is the variance among populations, and $\delta_{2 s}$ is the variance within populations.

\section{Data Analyses}

Data on six phenotypic traits of 93 R. crispus in nine populations were summarized with Microsoft Excel 2016, and means and standard deviations were calculated. Analyses of variance and Duncan analyses in SPSS 16.0 were used to analyze differences in phenotypic traits among populations. To quantify the sources of variation in the phenotypic traits of R. crispus, we divided sources of variation into intra- and interpopulation variation and intraindividual variation. Nested analyses of variance were performed with SPSS 16.0, and sources of variation and distribution ratios were explained by the variance components of each group. Pearson correlation analyses were used to analyze correlations between phenotypic traits and soil environmental factors, and R Language was used to perform UPGMA cluster analyses based on Euclidean distance and to draw a tree diagram. To avoid the influence of differences in scale, we normalized the average value of each trait.

\section{Results}

\section{Phenotypic variation in Rumex crispus}

The phenotypic traits of R. crispus differed significantly among populations (Table 3). Leaf area, leaf length, leaf width, leaf perimeter, and root diameter were largest in the WC population, followed by the CC population. The CC population had the thickest roots, followed by the WC population. The SH population had the smallest and most narrow leaves, the shortest perimeter, the largest leaf aspect ratio, and the thinnest roots. The leaf shape for this population was closer to elliptic. The Y population had the shortest leaf length and smallest leaf aspect ratio, and the leaf shape was closer to round.

The coefficient of variation quantifies the degree of variability in a trait. The larger the coefficient of variation, the more discrete the trait (Table 4). The average coefficient of variation among the six phenotypic traits was $46 \%$ (range $=23-81 \%$ ). The traits, listed from greatest to least variation, were on the order leaf area, leaf perimeter, root diameter, leaf length, leaf width, and leaf length-to-width ratio. The least variation was in the leaf length-to-width ratio ( $C V=23 \%)$, and the largest was in leaf area (CV = $81 \%$ ), which was about 3.5 times the leaf length-to-width ratio. We found great differences in the degree of variation in each population. Variation among populations, listed from greatest to least, was on the order Y, CC, SH, CA, CB, WC, WA, WB, and XG. The variation among populations ranged from $26-51 \%$; the population with the most variation was $Y(C V=51 \%)$, and the population with the least was XG $(C V=26 \%)$. In all populations, with two exceptions, the most and least variable traits were leaf area and leaf length-to-width ratio, respectively. The exceptions were that root thickness was the most variable trait in population WA, and leaf width was the least variable trait in population Y. 
Table 3

Analyses of variance in phenotypic traits among Rumex crispus populations exposed to long-term toxic metal pollution

\begin{tabular}{|c|c|c|c|c|c|c|}
\hline Population & $\begin{array}{l}\text { Leaf area } \\
\left(\mathrm{cm}^{2}\right)\end{array}$ & $\begin{array}{l}\text { Leaf length } \\
(\mathrm{cm})\end{array}$ & $\begin{array}{l}\text { Leaf width } \\
\text { (cm) }\end{array}$ & $\begin{array}{l}\text { Leaf perimeter } \\
\text { (cm) }\end{array}$ & $\begin{array}{l}\text { Leaf aspect } \\
\text { ratio }\end{array}$ & $\begin{array}{l}\text { Root diameter } \\
\text { (cm) }\end{array}$ \\
\hline CA & $\begin{array}{l}33.39 \pm \\
17.16 \mathrm{ab}\end{array}$ & $8.58 \pm 2.55 c$ & $4.71 \pm 1.38 a b$ & $26.35 \pm 9.26 a b$ & $1.86 \pm 0.39 c$ & $1.52 \pm 0.65 \mathrm{~cd}$ \\
\hline CB & $\begin{array}{l}33.95 \pm \\
17.52 \mathrm{ab}\end{array}$ & $8.13 \pm 2.77 a b$ & $5.36 \pm 1.61 b$ & $26.58 \pm 7.7 a b$ & $1.58 \pm 0.45 b$ & $1.56 \pm 0.44 \mathrm{~cd}$ \\
\hline $\mathrm{CC}$ & $\begin{array}{l}88.62 \pm \\
64.57 \mathrm{c}\end{array}$ & $13.61 \pm 5.52 f$ & $6.96 \pm 2.68 c$ & $40.3 \pm 20.4 c$ & $1.95 \pm 0.33 \mathrm{~cd}$ & $1.82 \pm 0.54 d$ \\
\hline WA & $\begin{array}{l}48.64 \pm \\
19.1 \mathrm{ab}\end{array}$ & $11.16 \pm 2.6 \mathrm{de}$ & $5.36 \pm 1.05 b$ & $36.4 \pm 14.72 c$ & $2.08 \pm 0.2 \mathrm{cde}$ & $1.58 \pm 0.69 \mathrm{~cd}$ \\
\hline WB & $\begin{array}{l}54.25 \pm \\
24.99 \mathrm{~b}\end{array}$ & $12.18 \pm 3.02 \mathrm{ef}$ & $5.67 \pm 1.2 b$ & $32.87 \pm 8.25 b c$ & $2.15 \pm 0.28 \mathrm{ef}$ & $1.28 \pm 0.36 b c$ \\
\hline WC & $\begin{array}{l}106.72 \pm \\
56.45 \mathrm{c}\end{array}$ & $17.04 \pm 4.85 \mathrm{~g}$ & $7.82 \pm 2.14 \mathrm{c}$ & $52.7 \pm 17.85 d$ & $2.22 \pm 0.41$ ef & $1.64 \pm 0.49 \mathrm{~cd}$ \\
\hline Y & $\begin{array}{l}28.57 \pm \\
25.35 a\end{array}$ & $6.34 \pm 3.26 a$ & $4.98 \pm 1.76 b$ & $23.48 \pm 12.33 a$ & $1.3 \pm 0.54 a$ & $0.92 \pm 0.35 \mathrm{ab}$ \\
\hline $\mathrm{SH}$ & $\begin{array}{l}27.11 \pm \\
19.94 a\end{array}$ & $8.94 \pm 3.25 c$ & $3.74 \pm 1.13 a$ & $23.02 \pm 8.02 a$ & $2.4 \pm 0.56 f$ & $0.46 \pm 0.17 a$ \\
\hline$X G$ & $\begin{array}{l}33.38 \pm \\
16.05 a b\end{array}$ & $9.6 \pm 2.51 \mathrm{bc}$ & $4.21 \pm 1.11 \mathrm{ab}$ & $26.91 \pm 7.2 \mathrm{ab}$ & $2.18 \pm 0.51 \mathrm{def}$ & $0.74 \pm 0.23 a$ \\
\hline Mean & $56.07 \pm 45.57$ & $11.31 \pm 4.77$ & $5.68 \pm 2.07$ & $34.17 \pm 16.23$ & $2 \pm 0.48$ & $1.35 \pm 0.61$ \\
\hline$F$ & $19.560^{\star \star}$ & $24.108^{\star \star}$ & $17.013^{\star \star}$ & $16.900^{\star \star}$ & $17.439^{\star \star}$ & $7.662^{* \star}$ \\
\hline
\end{tabular}

Table 4

Coefficients of variation for phenotypic traits among Rumex crispus populations exposed to long-term toxic metal pollution (\%)

\begin{tabular}{|c|c|c|c|c|c|c|c|}
\hline Population & Leaf area & Leaf length & Leaf width & Leaf perimeter & Leaf aspect ratio & Root diameter & Mean \\
\hline CA & 51 & 30 & 29 & 35 & 21 & 43 & 35 \\
\hline CB & 52 & 34 & 30 & 29 & 29 & 28 & 34 \\
\hline CC & 73 & 41 & 39 & 51 & 17 & 30 & 41 \\
\hline WA & 39 & 23 & 20 & 40 & 10 & 44 & 29 \\
\hline WB & 46 & 25 & 21 & 25 & 13 & 28 & 26 \\
\hline WC & 53 & 28 & 27 & 34 & 18 & 30 & 32 \\
\hline Y & 89 & 51 & 35 & 52 & 42 & 38 & 51 \\
\hline $\mathrm{SH}$ & 74 & 36 & 30 & 35 & 23 & 37 & 39 \\
\hline$X G$ & 48 & 26 & 26 & 27 & 11 & 32 & 28 \\
\hline Mean & 81 & 42 & 36 & 47 & 23 & 45 & 46 \\
\hline
\end{tabular}




\section{Phenotypic Differentiation And Sources Of Variation}

The variance components for phenotypic traits within and among populations differed markedly (Table 5). The average variance component percentages for the six phenotypic traits among and within populations were $93.17 \%$ and $6.09 \%$, and the remaining $0.74 \%$ were from individuals. The mean phenotypic differentiation coefficient was $93.84 \%$, and the phenotypic differentiation coefficient of each phenotypic trait was greater than $80 \%$.

Table 5

Variance components and phenotypic differentiation coefficients of phenotypic traits among Rumex crispus populations

\begin{tabular}{|c|c|c|c|c|c|c|c|}
\hline \multirow{2}{*}{$\begin{array}{l}\text { Phenotypic } \\
\text { trait }\end{array}$} & \multirow{2}{*}{$\begin{array}{l}\text { Random } \\
\text { error }\end{array}$} & \multicolumn{2}{|c|}{ Variance component } & \multicolumn{3}{|c|}{ Variance component percentage (\%) } & \multirow{2}{*}{$\begin{array}{l}\text { Phenotype } \\
\text { differentiation } \\
\text { coefficient (\%) }\end{array}$} \\
\hline & & $\begin{array}{l}\text { Among } \\
\text { populations }\end{array}$ & $\begin{array}{l}\text { Within } \\
\text { populations }\end{array}$ & $\begin{array}{l}\text { Within } \\
\text { individuals }\end{array}$ & $\begin{array}{l}\text { Among } \\
\text { populations }\end{array}$ & $\begin{array}{l}\text { Within } \\
\text { populations }\end{array}$ & \\
\hline Leaf area & 2.84 & 25700 & 1310 & 0.01 & 95.13 & 4.86 & 95.14 \\
\hline $\begin{array}{l}\text { Leaf } \\
\text { length }\end{array}$ & 0.30 & 319 & 13.23 & 0.09 & 95.93 & 3.98 & 96.02 \\
\hline Leaf width & 0.13 & 48.67 & 2.86 & 0.25 & 94.21 & 5.54 & 94.45 \\
\hline $\begin{array}{l}\text { Leaf } \\
\text { perimeter }\end{array}$ & 1.01 & 2970 & 176 & 0.03 & 94.38 & 5.58 & 94.41 \\
\hline $\begin{array}{l}\text { Leaf } \\
\text { aspect } \\
\text { ratio }\end{array}$ & 0.03 & 2.51 & 0.14 & 1.09 & 93.54 & 5.37 & 94.57 \\
\hline $\begin{array}{l}\text { Root } \\
\text { diameter }\end{array}$ & 0.06 & 1.82 & 0.24 & 3.00 & 85.82 & 11.19 & 88.47 \\
\hline Mean & & & & 0.74 & 93.17 & 6.09 & 93.84 \\
\hline
\end{tabular}

\section{Correlations between phenotypic traits of Rumex crispus and soil environmental factors}

Root diameter was positively correlated with all metals in the soil $(p<0.05$; Table 6$)$. Leaf area, leaf length, and leaf length-towidth ratio were negatively correlated with $\mathrm{Pb}, \mathrm{Zn}, \mathrm{Mn}$, and Fe. Leaf perimeter was negatively correlated with $\mathrm{Pb}, \mathrm{Zn}$, and $\mathrm{Mn}(\mathrm{p}<$ $0.05)$, but positively correlated with $\mathrm{Sn}, \mathrm{Cu}$, and $\mathrm{As}(\mathrm{p}<0.05)$. As and leaf length were also positively correlated $(\mathrm{p}<0.05)$.

Correlations between traits and metals, listed from greatest to least, were on the order root diameter, leaf length-to-width ratio, leaf length, leaf perimeter, leaf area, and leaf width. Leaf phenotypic traits were negatively correlated with $\mathrm{pH}(\mathrm{p}<0.05)$ and positively correlated with organic matter, total phosphorus, and total nitrogen $(p<0.05)$. Root diameter was negatively correlated with total nitrogen $(p<0.05)$. Correlations between traits and physical and chemical properties of the soil, listed from greatest to least, were on the order leaf length, leaf area, leaf perimeter, leaf width, root diameter, and leaf aspect ratio.

The comprehensive correlation between phenotypic traits and soil factors was the sum of the absolute values of the significant correlations of each trait, listed from greatest to least: organic matter, $\mathrm{Zn}, \mathrm{Mn}, \mathrm{Pb}, \mathrm{Fe}, \mathrm{pH}$, total nitrogen, total phosphorus, $\mathrm{As}$, Sn, $\mathrm{Cu}$, and soil moisture. Metal content related to phenotypic traits, listed from largest to smallest, was on the order $\mathrm{Zn}, \mathrm{Mn}, \mathrm{Pb}, \mathrm{Fe}$, As, Sn, and Cu. Relations between physical and chemical properties of the soil and phenotypic traits, listed from largest to smallest, were on the order organic matter, $\mathrm{pH}$, total nitrogen, total phosphorus, and soil moisture. 
Table 6

Correlations between phenotypic characteristics of Rumex crispus and soil factors

\begin{tabular}{|c|c|c|c|c|c|c|c|}
\hline Soil Factor & Leaf area & Leaf length & Leaf width & Leaf perimeter & Leaf aspect ratio & Root diameter & Sum $|r|$ \\
\hline Sn & 0.049 & 0.085 & 0.089 & $0.161^{* *}$ & -0.019 & $0.311^{\star \star}$ & 0.472 \\
\hline $\mathrm{Pb}$ & $-0.145^{\star}$ & $-0.250^{\star \star}$ & -0.011 & $-0.152^{\star}$ & $-0.441^{\star *}$ & $0.269^{* *}$ & 1.257 \\
\hline Zn & $-0.179^{\star *}$ & $-0.292^{\star *}$ & -0.057 & $-0.198^{\star *}$ & $-0.443^{\star *}$ & $0.313^{\star \star}$ & 1.425 \\
\hline $\mathrm{Mn}$ & $-0.213^{\star \star}$ & $-0.315^{\star \star}$ & -0.085 & $-0.224^{\star \star}$ & $-0.429^{\star \star}$ & $0.211^{*}$ & 1.392 \\
\hline $\mathrm{Fe}$ & $-0.174^{\star *}$ & $-0.214^{\star *}$ & -0.05 & -0.081 & $-0.323^{\star \star}$ & $0.261^{*}$ & 0.972 \\
\hline $\mathrm{Cu}$ & 0.025 & 0.083 & 0.064 & $0.138^{*}$ & 0.009 & $0.291^{\star \star}$ & 0.429 \\
\hline As & 0.101 & $0.162^{\star *}$ & 0.104 & $0.213^{\star *}$ & 0.087 & $0.273^{\star \star}$ & 0.648 \\
\hline SWC & 0.069 & 0.017 & 0.012 & -0.073 & 0.037 & 0.038 & 0 \\
\hline $\mathrm{pH}$ & $-0.224^{\star \star}$ & $-0.163^{\star \star}$ & $-0.199^{\star \star}$ & $-0.147^{\star}$ & -0.01 & -0.123 & 0.733 \\
\hline SOM & $0.315^{\star *}$ & $0.372^{\star \star}$ & $0.222^{\star \star}$ & $0.273^{\star *}$ & $0.308^{* \star}$ & -0.185 & 1.49 \\
\hline TP & $0.154^{*}$ & $0.176^{\star *}$ & $0.130^{*}$ & $0.221^{\star *}$ & 0.089 & 0.113 & 0.681 \\
\hline $\mathrm{TN}$ & $0.167^{\star \star}$ & $0.208^{\star \star}$ & 0.121 & $0.143^{*}$ & $0.170^{\star *}$ & $-0.225^{\star}$ & 0.688 \\
\hline
\end{tabular}

\section{Clustering Of Populations Based On Phenotypic Traits}

The nine R. crispus populations clustered based on the six phenotypic traits. After dividing by the Euclidean distance of 2.5, we divided the nine R. crispus populations into three groups (Fig. 1) not strictly clustered by geographic distance. The two populations not exposed to pollution, SH and XG, were a group.

\section{Discussion}

\section{Ecological differentiation in Rumex crispus after exposure to persistent toxic metal pollution}

The phenotypic traits of the R. crispus population contaminated by long-term toxic metal pollution in this mining area were quite different from those of populations that had not been exposed to pollution (Fig. 1). Phenotypic variation in plants is inseparable from their genes and the environment in which they grow. Rich morphological variation in plants is a manifestation of their ability to adapt to heterogeneous environments [2]. Plant leaves are more sensitive to different environments than other traits. Leaves are crucial to photosynthesis, respiration, and water exchange. They are the starting point for material circulation and energy flow. Leaves can directly affect the basic behavior and function of plants and can be a main indicator of plant genetic variation, which in turn reflects the survival strategies plants use to adapt to environmental changes $[13,14]$.

The six phenotypic traits we studied (leaf area, leaf length, leaf width, leaf perimeter, leaf length-to-width ratio, and root diameter) across the nine R. crispus populations differed significantly among populations, which indicates that this plant has abundant phenotypic variation. The coefficient of variation measures the degree of variation in a trait. A larger coefficient of variation indicates greater variation and more abundant diversity. The average coefficient of variation for the six phenotypic traits was $46 \%$, 
and variation in all phenotypes ranged from $26 \%$ to $51 \%$, which indicates that phenotypic variation in R. crispus populations was great, and these plants are highly adaptable to heterogeneous environments.

The six phenotypic traits of R. crispus, listed from greatest to least coefficient of variation, were on the order leaf area, leaf perimeter, root diameter, leaf length, leaf width, and leaf length-to-width ratio. The leaf length-to-width ratio had the least variation within populations $(\mathrm{CV}=24 \%)$ and the most stability, but differences among populations were significant in analyses of variance, which indicates that the trait is variable among populations but stable within populations. Leaf area had the largest variation (CV $=81 \%$ ), which shows that it has the least stability but high plasticity and thus is susceptible to the influence of individual development and environment. It differed significantly within and among populations.

\section{Reasons for ecological differentiation in Rumex crispus populations after exposure to continuous toxic metal pollution}

A total of $93.17 \%$ of the variation in the six phenotypic traits measured in these nine R. crispus populations originated from interpopulation variation, which was much higher than intrapopulation variation (6.09\%) or intraindividual variation (0.74\%). The mean phenotypic differentiation coefficient was $93.84 \%$, which indicates that phenotypic variation among populations accounted for $93.84 \%$, within-population variation accounted for $6.16 \%$, and the contribution among populations was 15 times that within populations. Once again, interpopulation variation was the main source of phenotypic variation in R. crispus. The greater genetic differentiation among populations and the low genetic diversity within populations could be attributed to genetic segregation among different populations, which is likely due to decreased gene flow caused by severe habitat fragmentation [15-17]. This could also explain why phenotypic differentiation has occurred among R. crispus populations in the mining area despite the limited geographic distribution of these populations.

\section{Adaptive mechanisms of Rumex crispus exposed to persistent toxic metal pollution}

The phenotypic characteristics of R. crispus populations growing in the mining area are the result of long-term adaptation to soil toxic metal pollution. R. crispus growing in the mining area generally has only one main root and almost no fibrous roots, and its main roots are thicker. The root diameter is mostly greater than $1 \mathrm{~cm}$. The coefficient of variation for root diameter was also greater, at $45 \%$, which indicates that variation in root diameter is high among different populations. The correlation between root diameter and soil metal factors was the strongest $(p<0.05$; Table 6$)$, which means that the more severe the toxic metal pollution

in the soil, the thicker the root. R. crispus is similar to Arabis alpina L., which has larger root diameters in locations with high levels of toxic metals [18]. The increase in root diameter may be due to the thickening of the root epidermis to reduce the absorption of toxic metal elements.

The roots of R. crispus growing in the mining area are generally long. The average root length of the plants in the area was as long as $20 \mathrm{~cm}$, and the longest root was $30 \mathrm{~cm}$. This is different from eggplant, which inhibit root elongation under high concentrations of heavy metals [19], but similar to Sedum alfredii, the concentrations of Zn of S. alfredii were positively correlated with root length [20]. This may have to do with the resistance of different plants to different heavy metals, and R. crispus is a plant that is resistant to a variety of heavy metals [12]. Therefore, the roots of the plant in the mining area were long and thick, which contributes to good growth despite continuous metal pollution.

The leaf area, leaf length, and leaf aspect ratio of R. crispus were negatively correlated with $\mathrm{Pb}, \mathrm{Zn}, \mathrm{Mn}$, and Fe $(\mathrm{p}<0.05)$, which is similar to the response of Arachis hypogaea L. to heavy metals-the increase in concentrations of $\mathrm{Zn}, \mathrm{Cu}$ and $\mathrm{Cd}$ leads to a decrease in leaf area [21]. Overall, the phenotypic traits of R. crispus show that underground growth is better than aboveground growth for populations that experience long-term persistent toxic metal pollution. Under conditions of such pollution, plants tend to have a reduced leaf area, and underground growth leads to the morphological development of plants in the direction of dry biochemicals $[22,23]$. R. crispus in the polluted area needs a longer root system to absorb water to adapt to physiological dehydration caused by heavy metal pollution, and the smaller leaf area may also be to cope with physiological water shortage,

Page $9 / 12$ 
reduce transpiration and improve adaptability to metal pollution. This xeromorphic adaptive trait variation has also occurred in plants in other metal-contaminated areas $\llbracket$ such as Arabidopsis arenosa from a lead zinc waste heap in southern Poland [24],and this trait variation may be heritable. It is through morphological variation in the direction of dry biochemicals that R. crispus can survive in this mining area, which has long been polluted with toxic metals.

\section{Conclusions}

In a heterogeneous environment characterized by toxic metal pollution in a mining area, Rumex crispus has rich phenotypic variation within and among populations, and a large degree of phenotypic differentiation has occurred among populations. Morphological differences between populations growing in polluted and unpolluted areas are also obvious. R. crispus adapts to long-term continuous toxic metal pollution by increasing underground growth and reducing aboveground growth. Finally, ecological differentiation has occurred among different populations.

\section{Declarations}

\section{Acknowledgments}

We thanks to Peng Wang, Luo-Qi Zhao, Ting Li for their assistance during plant sampling.

\section{Authors' contributions}

CD conceived and funded the study. YZ and SY analyzed the data and wrote the first draft. YZ, HY, YW and CT conducted the field work. CL and YZ provided editorial advice. All authors read and approved the final manuscript.

\section{Competing interests}

The authors declare that they have no competing interests.

\section{Availability of data and materials}

The datasets supporting the conclusions of this article are included within the article. Raw data are available from the corresponding author upon reasonable request.

\section{Consent to publish}

Not applicable.

\section{Ethics approval and consent to participate}

We declare that our experiments were performed in the respect of ethical rules.

\section{Funding}


This research was supported by National Natural Science Foundation of China (31670522), Key R \& D Special Project of Yunnan Province of China (S29017BC041).

\section{References}

1. Zhang L, Song FB, Wang XB: Research satus and countermeasures of heavy metal pollution in urban soils of China. Forest Research 2004, 26(2):113-117.

2. Saenger $P$, West PW: Phenotypic variation of the mangrove species Avicennia marina (Forssk.) Vierh. from seven provenances around Australia. Aquatic Botany 2018, 149:28-32.

3. Soliman M, El-Shazly M, Abd-El-Samie E, Fayed H: Variations in heavy metal concentrations among trophic levels of the food webs in two agroecosystems. African Zoology 2019, 54(1):21-30.

4. Zhang CQ, Ji ZF, Lin LL, Zhao RH, Wang YL: Phenotypic Diversity of Acer mono Maxim Population. Acta Ecologica Sinica 2015, 35(16):5343-5352.

5. Wang Q. Population ecological differentiation of Vicia faba L. and Zea may L. under persistent pollution of Pb, Cd. M.S. thesis. Yunnan University. China; 2013.

6. Ji M, Deng J, Yao B, Chen R, Fan Z, Guan J, Li X, Wu F, Niklas KJ: Ecogeographical variation of 12 morphological traits withinPinus tabulaeformis: the effects of environmental factors and demographic histories. Journal of Plant Ecology 2017, 10(2):386-396.

7. Pfennigwerth AA, Bailey JK, Schweitzer JA: Trait variation along elevation gradients in a dominant woody shrub is population-specific and driven by plasticity. AoB Plants 2017, 9(4):plx027.

8. Skaien $\mathrm{CL}$, Arcese P, Sankaran M: Spatial variation in herbivory, climate and isolation predicts plant height and fruit phenotype in Plectritis congesta populations on islands. Journal of Ecology 2018, 106(6):2344-2352.

9. Skrajna T, Kubicka H, Gozdowski D: Phenotypic and Genotypic Variation of Declining Segetal Flora: The Case of Stachys annua (Lamiaceae) Populations Established in North-Eastern Poland. Polish Journal of Ecology 2018, 66(1):23-35.

10. Shu X, Yang ZL, Yang X, Duan HP, Yu HH, Liu RN: Variation in traits of magnolia officinalis seedlings from different provenances and their principal component analysis. Journal of Wuhan Botanical Research 2010, 28:623-30.

11. Hang Li, Dahua Li, Tangfu Xiao, Libin He, Zengping Ning, Yan Shuang: Geochemistry and environmental effect of cadmium in the super-large Jinding Pb-Zn deposit, Yunnan Province, China. Chinese Journal of Geochemistry 2019, 27(1):21-27.

12. Xue X, Liu G: Resistance and Distribution to Heavy Metals of Zoysia sinica hance and Rumex crispus. Advanced Materials Research 2014, 1010-1012:117-120.

13. Vendramini F, Díaz S, Gurvich DE, Wilson PJ, Thompson K, Hodgson JG: Leaf traits as indicators of resource-use strategy in floras with succulent species. New Phytologist 2002, 154:147-157.

14. Song GY, He NP, Hou JH: Changes in Leaf Calorific Value in Main Chinese Forests and Its Influencing Factors. Forest Research 2016, 29(1):133 139.

15. Luo XY, Tang GD, Xu H , Zhuang XY, Zheng WX, Zeng M: Genetic diversity of three endemic and endangered species of the family Theaceae in Guangdong. Biodiversity Science 2005, 13(2):112-121.

16. Zhang JF, Kimatu J N, Guo WL, Liu B: Habitat fragmentation causes rapid genetic differentiation and homogenization in natural plant populations - A case study in Leymus chinensis. African Journal of Biotechnology 2009, 8(15):3440-3447.

17. Zhao Y, Vrieling K, Liao H, Xiao M, Zhu Y, Rong J, Zhang W, Wang Y, Yang J, Chen J et al: Are habitat fragmentation, local adaptation and isolation-by-distance driving population divergence in wild rice Oryza rufipogon? Mol Ecol 2013, 22(22):55315547.

18. Li Zr, Colinet G, Zu YQ, Wang JX, An LZ, L Q, Niu XY: Species diversity of Arabis alpina L. communities in two Pb/Zn mining areas with different smelting history in Yunnan Province, China. Chemosphere 2019, 233:603-614.

19. Korpe DA, Aras S: Evaluation of copper-induced stress on eggplant (Solanum melongena L.) seedlings at the molecular and population levels by use of various biomarkers. Mutat Res 2011, 719(1-2):29-34.

Page $11 / 12$ 
20. Li TQ, Yang XE, He ZL, Yang JY: Root Morphology and Zn ${ }^{2+}$ Uptake Kinetics of the Zn Hyperaccumulator of Sedum alfredii Hance. Journal of Integrative Plant Biology 2005, 47(8):927-934.

21. Shi G, Cai Q: Leaf plasticity in peanut (Arachis hypogaea L.) in response to heavy metal stress. Environmental and Experimental Botany 2009, 67(1):112-117.

22. Wang H X. Pollution Ecology. Higher Education Press. China; 2012.

23. Zał,ecka R, M.Wierzbicka: The adaptation of Dianthus carthusianorum L. (Caryophyllaceae) to growth on a zinc-lead heap in southern Poland. Plant and Soil 2002, 246:249-257.

24. Przedpełska E, Wierzbicka M: Arabidopsis arenosa (Brassicaceae) from a lead-zinc waste heap in southern Poland - a plant with high tolerance to heavy metals. Plant and Soil 2007, 299(1-2):43-53.

\section{Figures}

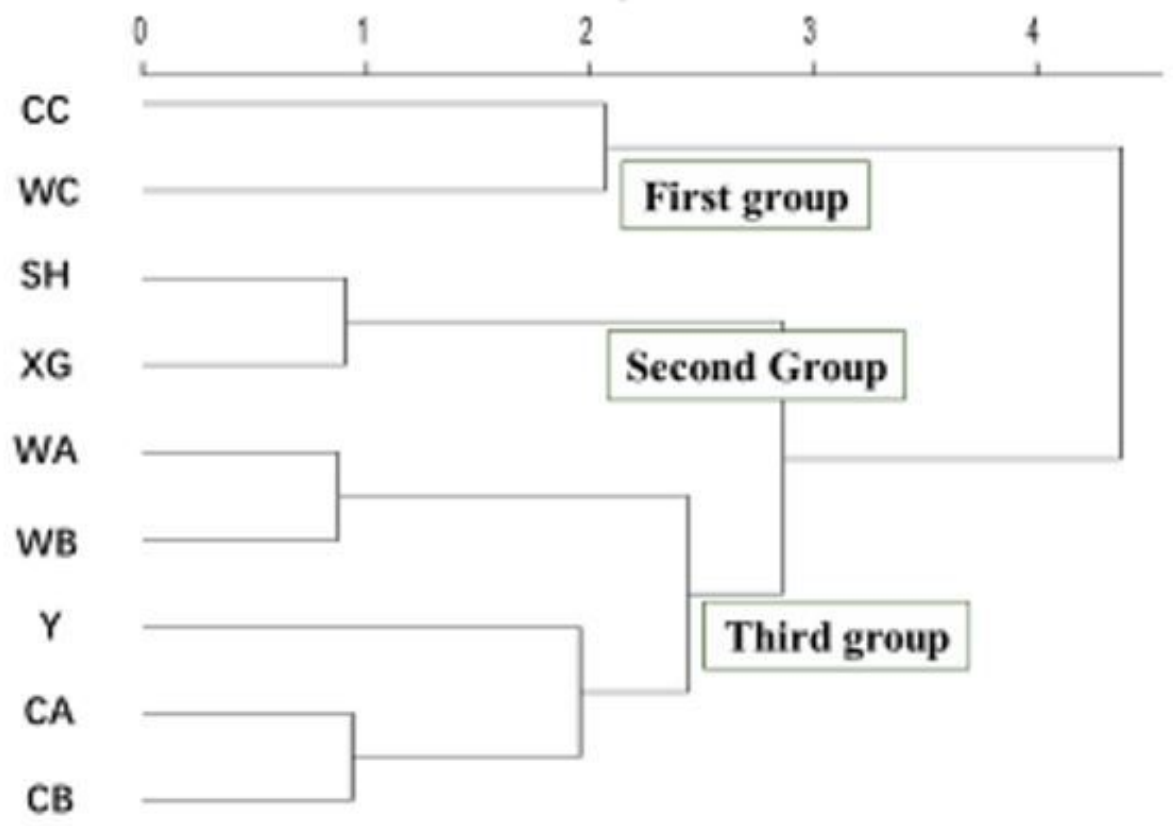

\section{Figure 1}

Cluster analysis of nine Rumex crispus populations based on variation in phenotypic traits. 